\title{
Organic and inorganic sources of zinc, copper and selenium in diets for dairy cows: intake, blood metabolic profile, milk yield and composition
}

\section{Cristina Simões Cortinhas ${ }^{1}$, José Esler de Freitas Júnior ${ }^{2}$, Julianne de Rezende Naves ${ }^{1}$, Marco Aurélio de Felicio Porcionato ${ }^{1}$, Luís Felipe Prada e Silva ${ }^{1}$, Francisco Palma Rennó ${ }^{1}$, Marcos Veiga dos Santos ${ }^{1}$}

\footnotetext{
${ }^{1}$ Departamento de Nutrição e Produção Animal, Faculdade de Medicina Veterinária e Zootecnia, USP. Av. Duque de Caxias Norte, 225, 13635-900, Pirassununga, SP, Brasil.

${ }^{2}$ Departamento de Nutrição e Produção Animal , Faculdade de Ciências Agrárias e Veterinárias, UNESP, Jaboticabal, SP, Brasil.
}

\begin{abstract}
The present study was carried out with the objective of evaluating the effects of feeding dairy cows with organic or inorganic sources of zinc $(\mathrm{Zn})$, copper $(\mathrm{Cu})$ and selenium $(\mathrm{Se})$ on blood concentrations of these minerals, blood metabolic profiles, nutrient intake and milk yield and composition. Nineteen Holstein cows were selected and randomly assigned to two groups for receiving organic $(n=9)$ or inorganic $(n=10)$ sources of $\mathrm{Zn}, \mathrm{Cu}$ and Se from 60 days before the expected date of calving to 80 days of lactation. Samples of feed, orts and milk were collected for analysis. Body condition score (BCS) was determined and blood samples were collected for analysis of $\mathrm{Zn}, \mathrm{Cu}$ and $\mathrm{Se}$ concentrations, as well as for metabolic profile. Supplying organic or inorganic sources of $\mathrm{Zn}, \mathrm{Cu}$, and $\mathrm{Se}$ did not affect dry matter and nutrient intake, blood metabolic profile, milk yield and composition, plasma concentration of these minerals, and BCS or change the BCS in cows from 60 days before the expected date of calving to 80 days of lactation. An effect of time was observed on all feed intake variables, plasma concentrations of $\mathrm{Zn}$ and $\mathrm{Se}$, milk yield, milk protein content, BCS and change in BCS.
\end{abstract}

Key Words: chelate, microminerals, nutrition, organic sources

\section{Introduction}

The trace minerals zinc $(\mathrm{Zn})$, copper $(\mathrm{Cu})$ and selenium (Se) are involved in vitamin metabolism, protein synthesis and the immune system of animals (Cortinhas et al., 2010). Trace mineral supplementation can affect health, reproductive status, immune function and lactation performance of dairy cows (Griffiths et al., 2007). Thus, appropriate mineral nutrition can be used to optimize the health and productivity of dairy cows (Ashmead et al., 2004).

Zinc plays an important role in DNA and RNA synthesis by increasing replication and cell proliferation (Spears et al., 2008), and in catalytic, structural and regulatory functions (McDowell, 2003). Copper has physiological functions related to cellular respiration, bone growth, heart function, development of connective tissue, myelination of the spinal cord and the processes of keratinization and pigmentation (McDowell, 2003). Selenium is involved mainly in antioxidant defense, immunity and metabolism of thyroid hormones (McDowell, 2003).

Traditionally, microminerals have been supplied as inorganic salts in animal feed (Uchida et al., 2001). Currently, there is much interest in using organic sources of minerals to supply these trace elements, which may reduce the interaction of minerals in the rumen with diet compounds, thereby preventing formation of insoluble complexes and consequently increasing their intestinal absorption (Spears, 2003).

Dairy cows require $\mathrm{Zn}, \mathrm{Cu}$ and $\mathrm{Se}$ to maintain antioxidant activity of their immune system (Weiss et al., 2005). Thus, use of trace elements from organic sources in animal nutrition (i.e, complexed, chelated amino acids, proteinates), which are more bioavailable (Spears, 2003) compared with those from inorganic sources, can be an important tool in maximizing milk production and maintaining health.

In previous research using the same experimental design, Cortinhas et al. (2010) studied effects of feeding organic sources of $\mathrm{Zn}, \mathrm{Cu}$ and Se to dairy cows on antioxidant enzymes and somatic cell count (SCC). Results from this research suggested that feeding organic sources of $\mathrm{Zn}, \mathrm{Cu}$ and $S e$ reduces the number of subclinical mastitis cases, but does not alter the concentration of serum superoxide dismutase, glutathione peroxidase or ceruloplasmin. Considering these findings, the authors hypothesized that the reduction of subclinical mastitis cases may be due to the alteration in blood levels of $\mathrm{Zn}, \mathrm{Cu}$ and Se or in nutrient intake during the pre-partum period. 
The objectives of the present study were to evaluate effects of feeding dairy cows organic sources of $\mathrm{Zn}, \mathrm{Cu}$ and $\mathrm{Se}$ on nutrient intake, blood concentrations of $\mathrm{Zn}, \mathrm{Cu}$ and Se, blood metabolic profile, milk yield and composition, and changes in body condition score (BCS) during the dry period and early lactation.

\section{Materials and Methods}

The study was conducted at the Department of Animal Nutrition and Production, School of Veterinary Medicine and Animal Science, Universidade de São Paulo, Pirassununga, São Paulo, Brazil, from September 2007 to August 2008.

Twenty four 60 -day pre-calving cows were selected and housed in individual stalls, with feed and water ad libitum. Due to illness in the postpartum period (i.e., three cases of retained placenta, one abortion, one abomasum displacement), five cows were excluded from the study. Thus, nineteen Holstein cows - six primiparous $(614 \mathrm{~kg} \pm 68.1$ body weight, BW) and thirteen multiparous (648 $\mathrm{kg} \pm 60.0$ BW) - were used. The cows were divided into two groups in a completely randomized design and matched according to calving number, BW, BCS and milk yield in their previous lactation (multiparous only). The experiment began 60 days before the expected date of calving (-60 d) and continued during 80 days of lactation.

Both groups were fed similar diets, formulated according to the NRC (2001) to meet the nutritional requirements according to their pregnancy and lactation stage: a) dry cows: 60 to 29 days before the expected date of birth ( $\mathrm{Zn}-42.8 ; \mathrm{Cu}-21.4$; and $\mathrm{Se}-0.4 \mathrm{mg} / \mathrm{kg}$ dry matter, DM); b) pre-partum: dry cows 28 days before the expected date of calving until the actual day of calving $(\mathrm{Zn}-47.6 ; \mathrm{Cu}$ -
24.7; and Se - $0.5 \mathrm{mg} / \mathrm{kg}$ of DM); c) lactation: 1 to 80 days of lactation ( $\mathrm{Zn}-47.0 ; \mathrm{Cu}-24.2 ;$ and $\mathrm{Se}-0.4 \mathrm{mg} / \mathrm{kg} \mathrm{DM})$. All diets were described by Cortinhas et al. (2010) (Table 1).

Treatments consisted of mineral mixtures containing either organic source of $\mathrm{Zn}, \mathrm{Cu}$ and $\mathrm{Se}$ (i.e., carbaminophosphochelate Novo Bovigold ${ }^{\circledR}$, mineral mixture, Tortuga, Companhia Zootécnica Agrária, São Paulo, Brazil) or inorganic $\mathrm{Zn}, \mathrm{Cu}$ and $\mathrm{Se}$ in their sulfate forms.

Briefly, carbaminophosphochelate was prepared from whole yeast used in industrial bread manufacture as the source of organic material, as well as specific minerals in inorganic form (i.e., $\mathrm{Zn}, \mathrm{Cu}$ and $\mathrm{Se}$ ), phosphate, salt, and sucrose. The mixture was exposed to controlled temperatures for periods of time, and the final reaction mixture was turned into powder using a spray-dryer. A typical analysis of carbaminophosphochelate was conducted by suspending $1 \mathrm{~g}$ of the material in pure water and, after centrifugation, the supernatant and the insoluble part were freeze-dried. Aliquots of both fractions were treated with $6 \mathrm{~N} \mathrm{HCl}$ at $120{ }^{\circ} \mathrm{C}$ for $72 \mathrm{~h}$ in closed ampules and the amino acid composition, as well as the amount of phosphate and specific added minerals, were determined. More than $90 \%$ of the minerals (i.e., $\mathrm{Zn}, \mathrm{Cu}, \mathrm{Se}$ ) were in the insoluble fraction. The amino acid composition was very similar to that found in non-treated yeast, but 0.75 of the amino acids were in the insoluble fraction. Therefore, the carbaminophosphochelate was a complex of specific mineral elements with yeast components and with products that resulted from their thermal treatment in the presence of sugar, minerals and phosphate salt.

The composition per kg of mineral mixture of the prepartum period was: Ca $-200 \mathrm{~g} ; \mathrm{P}-50 \mathrm{~g} ; \mathrm{Mg}-20 \mathrm{~g} ; \mathrm{S}-50 \mathrm{~g}$; $\mathrm{Na}-100$ g; Zn - 12,600 mg; Cu - 7,200 mg; Mn - 9,600 mg;

Table 1 - Proportion of ingredients and composition of diets, according to the stage of pregnancy and lactation of dairy cows

\begin{tabular}{|c|c|c|c|}
\hline Ingredients (g/kg DM) & Drying off (-60 to -29 days) & Pre-partum (-28 to 0 days) & Lactation ( 1 to 80 days) \\
\hline Corn silage & 799.4 & 742.8 & 470.6 \\
\hline Corn & 110.5 & 142.2 & 287.8 \\
\hline Soybean meal & 70.4 & 98.8 & 212.9 \\
\hline Urea & 9.8 & 7.9 & 4.8 \\
\hline Sodium bicarbonate & - & - & 7.2 \\
\hline Mineral mixture & 9.8 & 8.3 & 16.7 \\
\hline \multicolumn{4}{|l|}{ Diet composition $(\mathrm{g} / \mathrm{kg} \mathrm{DM})$} \\
\hline Dry matter & 417.1 & 447.3 & 611.9 \\
\hline Crude protein & 115.4 & 128 & 178.8 \\
\hline Neutral detergent fiber & 460 & 443.3 & 336.3 \\
\hline Acid detergent fiber & 289.4 & 274.1 & 195.7 \\
\hline Non-fiber carbohydrate & 332.3 & 339 & 393.9 \\
\hline Ether extract & 39.5 & 40.6 & 39.5 \\
\hline Calcium & 4 & 4.3 & 5.9 \\
\hline Phosphorus & 2.4 & 2.6 & 3.4 \\
\hline Net energy for lactation (Mcal $/ \mathrm{kg}$ DM) & 1.57 & 1.61 & 1.72 \\
\hline
\end{tabular}


Co - 66 mg; I - 240 mg; Se - 180 mg; vitamin A - 3,346,000 IU; vitamin D - 912,000 IU; vitamin E - 48,600 IU. During lactation, the composition per $\mathrm{kg}$ of mineral mixture was: Ca-248 g; P-50 g; Mg - 45 g; S - 20 g; Na - 50 g; Zn- 12,600mg; $\mathrm{Cu}$ - 7,200 mg; Mn - 9,600 mg; Co - 66 mg; I - 240 mg; Se $180 \mathrm{mg}$; vitamin A - 3,346,000 IU; vitamin D - 912,000 IU; vitamin E - 48,600 IU.

The mineral mixtures were weighed and packaged in paper bags and administered directly into the esophagus of the cows twice daily. The other ingredients were fed twice a day, in the total mixed diet fed ad libitum.

Corn silage, concentrates and orts were weighed daily to estimate individual animal DM intake. The amount of feed provided was calculated according to the DM intake of the previous day, to maintain 50 to $100 \mathrm{~g} / \mathrm{kg}$ of orts as fed. Samples of diet and orts were collected daily and stored $\left(-20^{\circ} \mathrm{C}\right)$ until analysis. Nutrient intake was estimated as the difference between the nutrient concentration in the feed and the orts.

Samples were ground using a $1 \mathrm{~mm}$ screen (Wiley Mill, Arthur A. Thomas, Philadelphia, PA, USA) to proceed DM analyses (AOAC, 1990; method 934.01) and to obtain organic matter (OM) by subtracting ash content from DM. Ether extract (EE) and lignin were determined according to methods described by AOAC (1990). The content of crude protein $(\mathrm{CP})$ was obtained by multiplying the total nitrogen content by 6.25 (AOAC, 1990).

The neutral detergent fiber (NDF) and acid detergent fiber (ADF) analyses were performed according to the methodology described by Van Soest and Mason (1991), using $\alpha$-amylase without addition of sodium sulfite when determining NDF (AOAC, 1990). The levels of non-fiber carbohydrates (NFC) were calculated according to Hall (2000), where: $\mathrm{NFC}=[(\% \mathrm{CP}-\% \mathrm{CP}$ urea $+\%$ urea $)+\% \mathrm{EE}+\%$ ash $+\%$ NDF)] .

Calcium $(\mathrm{Ca})$ and potassium $(\mathrm{K})$ were determined by atomic absorption spectrometry (Zagatto et al., 1979), and phosphorus (P) by colorimetry (Sarruge et al., 1974). Concentrations of $\mathrm{Zn}$ and $\mathrm{Cu}$ from diet and orts were analyzed by inductively coupled plasma on an optical emission spectrometer (ICP-OES) according to the AOAC methodology (method 985.01). The dietary Se concentration was determined after $700 \mathrm{mg} / \mathrm{g}$ perchloric acid digestion and subsequent fluorimetric reading, followed by the diamino-naphthalene procedure (Olson et al., 1975).

Blood samples were collected 60 days before the expected date of calving and on days 1, 40 and 80 of lactation to determine $\mathrm{Zn}, \mathrm{Cu}$ and $\mathrm{Se}$ concentrations. Samples were collected in heparinized vacutainer tubes by coccygeal venipuncture, centrifuged at $158 \mathrm{x}$ g for $15 \mathrm{~min}$ at room temperature, and plasma was stored at $-20{ }^{\circ} \mathrm{C}$ until analysis. Zinc and $\mathrm{Cu}$ analysis were according to Fick et al. (1979), and Se as described by Olson et al. (1975). For the blood metabolic profile analysis, samples were collected weekly throughout the experimental period by coccygeal venipuncture, prior to the morning feeding. Samples were collected for measurement of blood glucose (GL), nonesterified fatty acids (NEFA), $\beta$-hydroxybutyrate, total cholesterol(TC), HDL-cholesterol (HDL), total protein(TP), albumin, urea and blood urea N (BUN), and the enzymes aspartate aminotransferase, gammaglutamyltransferase and alkaline phosphatase.

Immediately after collection, samples were centrifuged at $2000 \times \mathrm{g}$ for 15 minutes at room temperature for serum separation. Serum was transferred to plastic tubes, identified and stored at $-20{ }^{\circ} \mathrm{C}$ until analysis.

Commercial Laborlab ${ }^{\circledR}$ kits (Laborlab, Guarulhos, SP, Brazil) were used for analyses of GL (Laborlab, 02200), TC (Laborlab, 01400), HDL (Laborlab, 08900), TP (Laborlab, 03800), albumin (Laborlab, 09800), urea (Laborlab, 02800), aspartate aminotransferase (Laborlab, 06500), gammaglutamyltransferase (Laborlab, 09900) and alkaline phosphatase (Laborlab, 09800) and, in the same way, with Randox ${ }^{\circledR}$ kits (Randox Laboratories, Crumlin, UK) for $\beta$-hydroxybutyrate (Randox, RB 1007) and NEFA (Randox, FA115). Blood ureic $\mathrm{N}$ was determined indirectly as: urea/2.14 (Gutmann \& Bergmeyer, 1974). The method used was enzymatic colorimetric endpoint for GL, TC, HDL, TP, albumin, BUN and NEFA, or kinetic method for urea, aspartate aminotransferase, gammaglutamyltransferase, alkaline phosphatase and $\beta$-hydroxybutyrate. Reading was made with an automatic biochemistry analyzer (Automatic System of Biochemistry Model-SBA-200 Modern Laboratory Equipment Company, MLEC $^{\circledR}$ - Barueri, São Paulo, Brazil). Analyses of NEFA were made in microplates and read with a micro-plate reader (ASYS Brand, Model Expert Plus UV-340- Analytic, São Paulo, Brazil).

For analysis of HDL concentration, $200 \mu \mathrm{L}$ of the sample were pipetted into $2.5 \mathrm{ml}$ tubes along with $100 \mu \mathrm{L}$ of single precipitating reagent (Modern Laboratory Equipment Company, MLEC ${ }^{\circledR}$-1763) at a 2:1 ratio and manually mixed by gentle inversion for $20 \mathrm{~s}$. Samples were left to sit for 10 minutes. Subsequently, the prepared samples were centrifuged for 15 minutes at $2700 \mathrm{x}$ g at room temperature and the HDL molecules linked to cholesterol were determined by Auto Chemistry System (Model-SBA-200 - Modern Laboratory Equipment Company, MLEC ${ }^{\circledR}$ - Barueri-São Paulo, Brazil).

Cows were milked twice daily and individual milk yields were recorded per milking. Milk was sampled weekly, from 
day 15 of lactation during the morning milkings, into plastic flasks with $8 \mathrm{mg}$ of bronopol as a preservative. Fat, lactose, crude protein and total solids (TS) were determined by infrared absorption (Bentley 2000, Bentley Instrument Inc., Chaska, MN, USA).

Determination of the all BCS of cows was completed at day -60 in relation to the parturition, at calving, at the end of the experiment, and every two weeks throughout the experiment, according to Edmonson et al. (1989), which is based on visual assessments of body condition at specific points in the body of the cow, ranging through a scale of 1 to 5 , with subunits of 0.25 points, regardless of the cow weight or size (i.e., height, thoracic girth, length). In order to assess the pattern of body reserve mobilization, changes in BCS were calculated.

Nutrient intakes, milk yield and composition, plasma concentrations of $\mathrm{Zn}, \mathrm{Cu}$ and $\mathrm{Se}, \mathrm{BCS}$ and changes in BCS were analyzed for effects of treatment (i.e., organic versus inorganic), time (i.e., weeks pre- and post-partum), and the time $\times$ treatment interaction with repeated measures over time, using PROC MIXED of SAS (Statistical Analysis System, version 8), according to the model:

$Y_{\mathrm{ij}}=\mu+\beta_{\mathrm{i}}+\gamma_{\mathrm{j}}+(\beta * \gamma)_{\mathrm{ij}}+e_{\mathrm{ij}}$

with: $Y_{\mathrm{ij}}=$ value observed for the variable of the ith treatment in the jth week; $\mu=$ general constant; $\beta_{i}=$ effect of the ith treatment; $\gamma_{\mathrm{j}}=$ effect of the jth time; $(\beta * \gamma)_{\mathrm{ij}}=$ interaction effect of the ith treatment in the $\mathrm{jth}$ time; and $e_{\mathrm{ij}}=$ error term. The significance level adopted was $\alpha=0.05$.

\section{Results and Discussion}

There was no effect of treatment or treatment $\times$ time on DM intake, or on the intake of OM, CP, NDF, NFC, EE, Ca, $\mathrm{P}, \mathrm{K}, \mathrm{Zn}, \mathrm{Cu}$ and Se either pre-partum or during lactation (Table 2). The sources of $\mathrm{Zn}, \mathrm{Cu}$ and $\mathrm{Se}$ were weighed and administered directly into the esophagus of the cows. Given that the intake of minerals was similar between the treatments, the objective of evaluating effects of $\mathrm{Zn}, \mathrm{Cu}$ and Se sources, without interference of different quantities consumed, was achieved.

Average total intake of $\mathrm{Zn}$ for animals fed organic and inorganic sources during pre-partum and lactation (497.6 and $762 \mathrm{mg} /$ day, respectively) was lower than the recommendations of the NRC (2001) (660 and $902 \mathrm{mg} / \mathrm{day}$, respectively). Copper intake (average of organic and inorganic source) during pre-partum and lactation (i.e., 257 and $394 \mathrm{mg} /$ day, respectively) was similar to the recommendations of the NRC (2001) (252 and $327 \mathrm{mg} /$ day, respectively). Average Se for animals fed organic and inorganic sources during pre-partum and lactation $(4.7$ and $6.6 \mathrm{mg} / \mathrm{day}$, respectively) was slightly higher than the recommendations of the NRC (2001) (4.3 and $5.7 \mathrm{mg} /$ day, respectively). Studies on the supply of different sources of micro minerals (Griffiths et al., 2007; Kinal et al., 2007a; Siciliano-Jones et al., 2008) did not estimate total nutrient intake.

In this study, there was an effect of time $(\mathrm{P}<0.01)$ on all intake variables in both periods, with a reduction during the last 3 weeks pre-partum and increase through the eighth

Table 2 - Effects of organic and inorganic sources of $\mathrm{Zn}, \mathrm{Cu}$ and $\mathrm{Se}$ on the intake of nutrients during pre-partum and lactation

\begin{tabular}{|c|c|c|c|c|c|c|c|c|c|c|c|c|}
\hline \multirow{3}{*}{ Variable } & \multicolumn{6}{|c|}{ Pre-partum (-60 days to parturition) } & \multicolumn{6}{|c|}{ Lactation (1 to 80 DIM) } \\
\hline & \multicolumn{3}{|c|}{ Source } & \multicolumn{3}{|c|}{ Probability } & \multicolumn{3}{|c|}{ Source } & \multicolumn{3}{|c|}{ Probability } \\
\hline & Organic & Inorganic & SEM & Source & Time & $\begin{array}{c}\text { Source } \times \\
\text { time }\end{array}$ & Organic & Inorganic & SEM & Source & Time & $\begin{array}{c}\text { Source } \times \\
\text { time }\end{array}$ \\
\hline DM (kg/day) & 10.0 & 10.3 & 0.17 & 0.718 & $<0.001$ & 0.453 & 15.5 & 16.1 & 0.30 & 0.656 & $<0.001$ & 0.678 \\
\hline DM (\%BW) & 1.5 & 1.6 & 0.03 & 0.382 & $<0.001$ & 0.648 & 2.6 & 2.8 & 0.05 & 0.245 & $<0.001$ & 0.654 \\
\hline OM (kg/day) & 9.5 & 9.8 & 0.16 & 0.702 & $<0.001$ & 0.477 & 14.7 & 15.3 & 0.28 & 0.658 & $<0.001$ & 0.680 \\
\hline NFC (kg/day) & 3.2 & 3.4 & 0.06 & 0.539 & $<0.001$ & 0.159 & 6.3 & 6.6 & 0.12 & 0.584 & $<0.001$ & 0.354 \\
\hline $\mathrm{EE}(\mathrm{kg} /$ day $)$ & 0.4 & 0.4 & 0.01 & 0.514 & $<0.001$ & 0.951 & 0.6 & 0.6 & 0.01 & 0.817 & $<0.001$ & 0.815 \\
\hline $\mathrm{Ca}$ (g/day) & 40.6 & 39.5 & 0.67 & 0.762 & $<0.001$ & 0.254 & 87.5 & 91.4 & 1.82 & 0.645 & $<0.001$ & 0.434 \\
\hline P (g/day) & 26.2 & 26.4 & 0.47 & 0.905 & 00.003 & 0.917 & 52.4 & 53.7 & 0.93 & 0.736 & $<0.001$ & 0.701 \\
\hline K (g/day) & 97.7 & 94.1 & 2.12 & 0.726 & $<0.001$ & 0.323 & 141.4 & 145.2 & 2.62 & 0.749 & $<0.001$ & 0.601 \\
\hline $\mathrm{Zn} \mathrm{(mg/day)}$ & 489.9 & 505.4 & 5.69 & 0.562 & $<0.001$ & 0.864 & 751.6 & 772.6 & 7.84 & 0.558 & $<0.001$ & 0.674 \\
\hline
\end{tabular}

SEM - standard error of mean; DIM - days in milk; DM - dry matter; OM - organic matter; CP - crude protein; NDF - neutral detergent fiber; NFC - non-fibrous carbohydrates; EE - ether extract. 
week of lactation. After calving, voluntary feed intake increases rapidly due to the increase in demand for nutrients targeted for lactation (Grummer, 1995). Grant et al (1995) found that the DMI increased approximately 1.5 to $2.5 \mathrm{~kg} /$ week during the first three weeks of lactation.

There were no effects of treatment on plasma concentrations of GL, NEFA, $\beta$-hydroxybutyrate, TC, CHDL, $\mathrm{TP}$, albumin, urea, BUN, $\beta$-hydroxybutyrate, alkaline phosphatase or $\beta$-hydroxybutyrate, either pre-partum or during lactation (Table 2). Similarly, Kinal et al. (2007a) did not observe effect of supplementation of organic $\mathrm{Zn}, \mathrm{Cu}$ or Mn from six weeks pre partum to three months of lactation on concentrations of urea and GL. However, a time effect was observed in this study for all variables during both periods, except for $\beta$-hydroxybutyrate pre-partum and concentrations of $\beta$-hydroxybutyrate and $\beta$-hydroxybutyrate during the first $80 \mathrm{~d}$ of lactation. The time effect was expressed by sharp reduction in concentrations of GL, TP and TC at calving, followed by a gradual increase during lactation.

There was an increase in the concentrations of albumin, CHDL, $\beta$-hydroxybutyrate, $\beta$-hydroxybutyrate, NEFA and $\beta$-hydroxybutyrate pre- and post-partum. Similarly, there was an increase in BUN, alkaline phosphatase and serum urea concentrations only pre-partum with a gradual reduction post-partum. Interactions between time and treatment occurred on CHDL and $\beta$-hydroxybutyrate concentrations pre-partum, and BUN and urea during lactation (Table 3). The time effects during the experimental period are associated to physiological processes that occur during the transition period, such as fetal growth, birth and early lactation.
Plasma concentrations of $\mathrm{Zn}, \mathrm{Cu}$ and $\mathrm{Se}$ were not altered by feeding organic or inorganic sources (Table 4). This result differs from Weiss et al. (2005), who reported an increase in Se serum concentrations of Holstein cows fed organic Se as compared with cows fed Se as sulphate. Other authors (Spears et al., 2004; Kinal et al., 2007b) also reported an increase in $\mathrm{Zn}$ in plasma in cattle fed organic or inorganic Zn. Similarly, Kinal et al. (2007a) reported an increase in plasma $\mathrm{Cu}$ concentration of dairy cows fed organic sources of $\mathrm{Zn}, \mathrm{Cu}$ and $\mathrm{Mn}$ compared with cows fed these minerals as sulphate.

Average concentrations of $\mathrm{Zn}$ in this study during the 60 days before the expected date of calving $(0.83 \mathrm{mg} / \mathrm{mL})$ and at parturition $(0.54 \mathrm{mg} / \mathrm{mL})$, were similar to those found by Goff et al. (1990) of $0.86 \mathrm{mg} / \mathrm{mL}$ and $0.58 \mathrm{mg} / \mathrm{mL}$, respectively. Goff et al. (1990) showed a sharp decline of plasma $\mathrm{Zn}$ concentration at parturition and a return to baseline levels 3 days postpartum.

Effect of time $(\mathrm{P}<0.01)$ was found on plasma concentrations of $\mathrm{Se}$ and $\mathrm{Zn}$, with a reduction in the $\mathrm{Zn}$ concentration pre-partum until calving, followed by an increase during lactation. Se concentration increased linearly $(\mathrm{P}<0.001)$ throughout pre- and post-partum, differing from Weiss et al. (2005) who observed a decrease in plasma concentration of Se in dairy cows at parturition. Values prepartum at $0.059 \mu \mathrm{g} / \mathrm{mL}$ and at parturition at $0.066 \mu \mathrm{g} / \mathrm{mL}$ in our study are lower than those reported by Stowe et al. (1992) at $0.07 \mu \mathrm{g} / \mathrm{mL}$ pre partum and $0.10 \mu \mathrm{g} / \mathrm{mL}$ at parturition.

A possible limitation of the current study is that no bioavailability data was available. Spears (2003) described

Table 3 - Effects of organic and inorganic sources of $\mathrm{Zn}, \mathrm{Cu}$ and Se on serum concentrations of glucose, non-esterified fatty acid (NEFA), $\beta$-hydroxybutyrate (BHBA), total cholesterol (TC), HDL cholesterol (CHDL), total proteins (TP), albumin, urea and blood urea nitrogen (BUN), and enzymes aspartate aminotransferase (AST), gammaglutamyltransferase (GGT) and alkaline phosphatase (ALP) during the periods pre-partum and lactation

\begin{tabular}{|c|c|c|c|c|c|c|c|c|c|c|c|c|}
\hline \multirow{3}{*}{ Variable } & \multicolumn{6}{|c|}{ Pre-partum } & \multicolumn{6}{|c|}{ Lactation (1 to 80 DIM) } \\
\hline & \multicolumn{3}{|c|}{ Source } & \multicolumn{3}{|c|}{ Probability } & \multicolumn{3}{|c|}{ Source } & \multicolumn{3}{|c|}{ Probability } \\
\hline & Organic & Inorganic & SEM & Source & Time & $\begin{array}{l}\text { Source } \times \\
\text { time }\end{array}$ & Organic & Inorganic & SEM & Source & Time & $\begin{array}{c}\text { Source } \times \\
\text { time }\end{array}$ \\
\hline Glucose (mg/dL) & 71.4 & 69.0 & 1.18 & 0.614 & 0.026 & 0.858 & 65.5 & 59.8 & 1.00 & 0.236 & 0.001 & 0.901 \\
\hline $\mathrm{TP}(\mathrm{mg} / \mathrm{dL})$ & 8.4 & 8.4 & 0.11 & 0.989 & 0.014 & 0.820 & 8.7 & 8.4 & 0.07 & 0.471 & 0.001 & 0.167 \\
\hline Albumin $(\mathrm{mg} / \mathrm{dL})$ & 2.8 & 2.8 & 0.02 & 0.843 & $<0.001$ & 0.252 & 2.9 & 2.8 & 0.02 & 0.561 & 0.033 & 0.107 \\
\hline CHDL (mg/dL) & 44.8 & 53.7 & 1.16 & 0.103 & 0.048 & 0.003 & 62.9 & 64.0 & 1.41 & 0.849 & $<0.001$ & 0.668 \\
\hline TC (mg/dL) & 80.1 & 86.3 & 1.28 & 0.205 & 0.003 & 0.510 & 115.1 & 117.3 & 2.15 & 0.759 & $<0.001$ & 0.004 \\
\hline Urea (mg/dL) & 43.9 & 36.3 & 0.10 & 0.121 & 0.042 & 0.318 & 41.6 & 34.7 & 0.86 & 0.110 & 0.016 & 0.028 \\
\hline BUN (mg/dL) & 20.5 & 17.0 & 0.47 & 0.140 & 0.030 & 0.304 & 19.4 & 16.2 & 0.40 & 0.111 & 0.016 & 0.031 \\
\hline $\operatorname{AST}(\mathrm{U} / \mathrm{L})$ & 49.3 & 48.3 & 1.28 & 0.761 & $<0.001$ & 0.482 & 62.1 & 55.5 & 1.32 & 0.200 & 0.015 & 0.838 \\
\hline GGT (U/L) & 3.8 & 3.3 & 0.08 & 0.152 & 0.054 & 0.564 & 4.3 & 3.8 & 0.09 & 0.420 & 0.573 & 0.954 \\
\hline ALP (U/L) & 32.3 & 40.8 & 1.30 & 0.157 & 0.010 & 0.082 & 29.4 & 35.4 & 0.96 & 0.211 & 0.019 & 0.708 \\
\hline BHB (mmol/L) & 0.5 & 0.5 & 0.01 & 0.854 & 0.020 & 0.001 & 0.7 & 0.6 & 0.03 & 0.295 & 0.795 & 0.895 \\
\hline NEFA (mmol/L) & 0.4 & 0.4 & 0.01 & 0.793 & 0.001 & 0.477 & 0,6 & 0.6 & 0.02 & 0.973 & $<0.001$ & 0.830 \\
\hline
\end{tabular}


Table 4 - Effects of supply of organic and inorganic sources of $\mathrm{Zn}, \mathrm{Cu}$ and $\mathrm{Se}$ on plasma concentrations of $\mathrm{Zn}, \mathrm{Cu}$ and $\mathrm{Se}$, body condition score (BCS) and changes in body condition score (CBCS) during pre-partum and lactation ( 1 to 80 days), and milk production, fat, protein, lactose and total solids in early lactation (i.e., 15 to 80 days)

\begin{tabular}{|c|c|c|c|c|c|c|}
\hline & \multicolumn{3}{|c|}{ Source } & \multicolumn{3}{|c|}{ Probability } \\
\hline & Organic & Inorganic & SEM & Source & Time & Source $\times$ time \\
\hline \multicolumn{7}{|l|}{ Plasma concentration } \\
\hline $\mathrm{Zn}(\mu \mathrm{g} / \mathrm{mL})$ & 0.67 & 0.69 & 0.03 & 0.799 & 0.002 & 0.604 \\
\hline $\mathrm{Cu}(\mu \mathrm{g} / \mathrm{mL})$ & 0.75 & 0.77 & 0.01 & 0.705 & 0.083 & 0.493 \\
\hline $\operatorname{Se}(\mu \mathrm{g} / \mathrm{mL})$ & 0.07 & 0.07 & 0.01 & 0.178 & $<0.001$ & 0.125 \\
\hline BCS (units) & 3.40 & 3.50 & 0.02 & 0.187 & $<0.001$ & 0.320 \\
\hline BCS changes (units) & -0.20 & -0.20 & 0.02 & 0.525 & $<0.001$ & 0.355 \\
\hline \multicolumn{7}{|l|}{ Milk yield and composition } \\
\hline Milk yield (kg/day) & 27.52 & 26.94 & 0.01 & 0.826 & $<0.001$ & 0.727 \\
\hline Fat (kg/day) & 0.85 & 0.82 & 0.01 & 0.838 & 0.135 & 0.300 \\
\hline Protein (kg/day) & 0.83 & 0.83 & 0.01 & 0.978 & 0.915 & 0.617 \\
\hline Lactose (kg/day) & 1.32 & 1.28 & 0.01 & 0.913 & 0.148 & 0.646 \\
\hline Fat $(\mathrm{g} / \mathrm{kg}$ of milk) & 3.01 & 3.02 & 0.04 & 0.846 & 0.965 & 0.649 \\
\hline Protein $(\mathrm{g} / \mathrm{kg}$ of milk) & 2.91 & 2.99 & 0.02 & 0.422 & 0.007 & 0.920 \\
\hline Lactose $(\mathrm{g} / \mathrm{kg}$ of milk ) & 4.59 & 4.63 & 0.01 & 0.678 & 0.169 & 0.540 \\
\hline Total solids ( $\mathrm{g} / \mathrm{kg}$ of milk) & 11.45 & 11.57 & 0.06 & 0.563 & 0.920 & 0.251 \\
\hline
\end{tabular}

SEM - standard error of the mean.

that organic source of trace minerals are more bioavailable than inorganic source; however, this higher bioavailability was completely determined. Traditionally, experiments on bioavailability of trace minerals require the use of purified basal diet with very low concentration of the studied mineral or higher levels of the mineral-trace tested (Vilela et al., 2011).

No effects of source of $\mathrm{Zn}, \mathrm{Cu}$ and Se occurred on milk yield and composition (Table 3), and there were no interactions between time $\times$ treatment. However, protein proportion declined to the 7 th week of lactation, followed by an increase in this variable after this period until the end of the experiment ( 80 days of lactation). Milk yield increased from the beginning of lactation to the 8th week of lactation. Considering the results obtained by Cortinhas et al. (2010), in which fewer cases of subclinical mastitis occurred, an increase on milk yield was expected by cows fed organic $\mathrm{Zn}, \mathrm{Cu}$ and Se. Nocek et al. (2006) reported an increase in fat production without changes in the SCC during the first lactation evaluated. Changes in milk production and composition regardless of SCC could be due to the involvement of $\mathrm{Zn}, \mathrm{Se}$ and $\mathrm{Cu}$ in other physiological processes (McDowell, 2003).

Impacts of the supply of organic trace minerals on milk yield and composition are variable. Kinal et al. (2007b) and Siciliano-Jones et al. (2008) reported effects of trace mineral supplementation with organic sources when compared with inorganic sources on milk yield and its components, but without changes on milk component. Griffiths et al. (2007) reported the same effects as Kinal et al. (2007b) and Siciliano-Jones et al. (2008) comparing a group of dairy cows supplied with complexed zinc, manganese, copper and cobalt and a group without organic supply. On the other hand, Nocek et al. (2006) observed effects of organic mineral sources on both milk yield and composition, while Ashmead et al. (2004) reported a cumulative effect on milk yield during three lactations with organic mineral supplementation, both authors comparing organic and inorganic sources.

Neither body condition score nor body condition score change were influenced by the supply of organic Zn, $\mathrm{Cu}$ and Se during pre- and post-partum (Table 3); this was expected since the DM intake and blood parameters did not differ. Results of body condition score were similar to those reported by Uchida et al. (2001) and Nocek et al. (2006), who did not observe effects of $\mathrm{Zn}, \mathrm{Mn}, \mathrm{Cu}$ or Co supplemented to dairy cows over three lactations on body condition score. Both body condition scoreand body condition score change were influenced by time in a similar manner, with an increase from the 8 th week to two weeks pre-partum. After two weeks pre-partum, both body condition score and body condition score change decreased until the fourth week post-partum.

\section{Conclusions}

Supplying zinc, copper, and selenium as organic rather than inorganic sources does not influence dry matter and nutrient intake, blood metabolic profile, milk yield and composition, plasma concentrations of these minerals or body condition scorein cows from 60 days before the expected date of calving to 80 days of lactation. 


\section{Acknowledgments}

The authors are grateful to Antonio Carlos da Silva Bueno, Gilmar Edson Botteon, José Garcia Moreno Franchini, Lucinéia Mestieri, and Clara Satsuki Mori for technical assistance in accomplishing this research project.

\section{References}

ASSOCIATION OF OFFICIAL ANALYTICAL CHEMISTS - AOAC. Official methods of analysis. 15.ed. Arlington: AOAC international, 1990. 1298p.

ASHMEAD, H.D.; SAMFORD, R.A. Effects of metal amino acid chelates or inorganic minerals on three successive lactations in dairy cows. International Journal Applied Research Veterinary Medicine, v.2, n.3, p.181-188, 2004.

CORTINHAS, C.S.; BOTARO, B.G.; SUCUPIRA, M.C.A. et al. Antioxidant enzymes and somatic cell count in dairy cows fed with organic source of zinc, copper and selenium. Livestock Science, v.127, n.1, p.84-87, 2010.

EDMONSON, A.J.; LEAN, I.J.; WEAVER, L.D. A body condition scoring chart for Holstein dairy cows. Journal of Dairy Science, v.72, p.68-78, 1989.

FICK, K.R.; MCDOWELL, L.R.; MILES, P.H. et al. Methods of mineral analysis for plant and animals tissues. Gainesville: Department of Animal Science, University of Florida, 1979. $92 \mathrm{p}$.

GOFF, J.P.; STABEL, J.R. Decreased plasma retinol, alphaTocopherol, and zinc concentration during the periparturient period: effect of milk fever. Journal of Dairy Science, v.73, n.11, p.3195-3199, 1990.

GRANT, R.J.; ALBRIGHT, J.L. Feeding behavior and management factors during the transition period in dairy cattle. Journal of Animal Science, v.73, p.2791-2803, 1995.

GRIFFITHS, L.M.; LOEFFLER, S.H.; SOCHA, M.T. et al. Effects of supplementing complexed zinc, manganese, copper and cobalt on lactation and reproductive performance of intensively grazed lactating dairy cattle on the South Island of New Zealand. Animal Feed Science and Technology, v.137, n.1-2, p.69-83, 2007.

GRUMMER, R.R. Impact of changes in organic nutrient metabolism on feeding the transition dairy cow. Journal of Animal Science, v.73, p.2820-2833, 1995.

GUTMANN, I.; BERGMEYER, H.U. Reagents for enzymatic analysis. In: BERGMEYER, H.U.; GAWEHN, K. (Eds.) Methoden der enzymatischen analyses. 3.ed. Weinheim: Verlag Chemie, 1974. v.2, p.1839-1842.

HALL, M.B. Calculation of non-structural carbohydrate content of feeds that contain non-protein nitrogen. Gainesville: University of Florida, 2000. p.A-25 (Bulletin, 339).

KINAL, S.; KORNIEWICZ, A.; SUPCZYÑSKA, M. et al. Effect of the application of bioplexes of zinc, copper and manganese on milk quality and composition of milk and colostrum and some indices of the blood metabolic profile of cows. Czech Journal of Animal Science, v.52, p.423-429, 2007a.

KINAL, S.; KORNIEWICZ, D.; JAMROZ, D. et al. The effectiveness of zinc, copper and manganese applied in organic forms in diets of high milk yielding cows. Journal of Food Agriculture \& Environment, v.5, p.189-193, 2007 b.

McDOWELL, L.R. Minerals in animal and human nutrition. 2.ed. Netherlands: Elsevier Science, 2003. 644p.

NOCEK, J.E.; SOCHA, M.T.; TOMLINSON, D.J. The effect of trace mineral fortification level and source on performance of dairy cattle. Journal of Dairy Science, v.89, n.7, p.2679-2693, 2006.

NATIONAL RESEARCH COUNCIL - NRC. Nutrient requirements of dairy cattle. 7.ed. Washington, D.C.: National Academy Press, 2001. 381p.

OLSON, O.E.; PALMER, I.S.; CARY, E.E. Modification of the official fluorimetric method for selenium in plants. Journal of Association of Official Analytical Chemists, v. 58 , n.1, p.117-121, 1975 .

SARRUGE, J.R.; HAAG, H.P. Análises químicas em plantas. Piracicaba: Departamento de Química Escola Superior Luiz de Queiroz, 1974. 56p.

SICILIANO-JONES, J.L.; SOCHA, M.T.; TOMLINSON, D.J. et al. Effect of trace mineral source on lactation performance, claw Integrity, and fertility of dairy cattle. Journal of Dairy Science, v.91, n.5, p.1985-1995, 2008.

SPEARS, J.W. Trace mineral bioavailability in ruminants. Journal of Nutrition, v.133, n.5, p.1506S-1509S, 2003.

SPEARS, J.W.; SCHLEGEL, P.; SEAL, M.C. et al. Bioavailability of zinc from zinc sulfate and different organic zinc sources and their effects on ruminal volatile fatty acid proportions. Livestock Production Science, v.90, n.1-2, p.211-217, 2004

SPEARS, J.W.; WEISS, W.P. Role of antioxidants and trace elements in health and immunity of transition dairy cows. The Veterinary Journal, v.176, n.1, p.70-76, 2008.

UCHIDA, K.; MANDBEVU, P.; BALLARD, C.S. et al. Effect of feeding a combination of zinc, manganese and copper amino acid complexes, and cobalt glucoheptonate on performance of early lactation high producing dairy cows. Animal Feed Science and Technology, v.93, n.3-4, p.193-203, 2001.

VAN SOEST, P.J.; MASON, V.C. The influence of Maillard reaction upon the nutritive value of fibrous feeds. Animal Feed Science and Technology, v.32, n.1, p.45-53, 1991.

VILELA, F.G.; ZANETTI M.A.; SARAN NETTO, A. et al. Bioavailability of organic and inorganic zinc sources in sheep. Arquivo Brasileiro de Medicina Veterinária e Zootecnia, v.63, n.2, p.448-455, 2011.

WEISS, W.P.; HOGAN, J.S. Effect of selenium source on selenium status, neutrophil function, and response to intramammary endotoxin challenge of dairy cows. Journal of Dairy Science, v.88, p.4366-4374, 2005.

ZAGATTO, E.A.G.; KRUG, F.J.; BERGAMIN FILHO, H. et al. Merzing in flow injection analysis. Part 2. Determination of calcium, magnesium and potassium in plant material by flow injection atomic and flame emission spectrometry. Analytica Chimica Acta, v.104, p.279-284, 1979. 